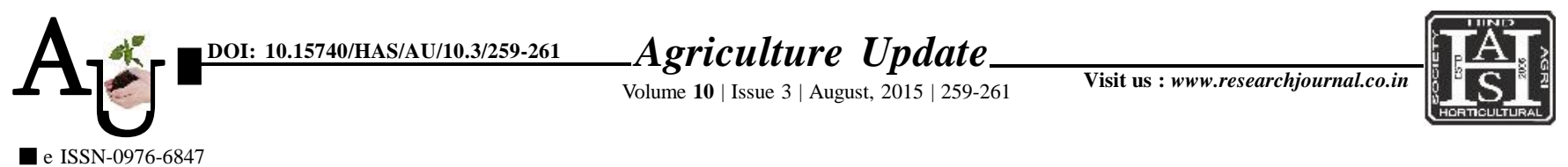

\title{
Rевенстн Автісі: Front line demonstration on effect of urea treatment of wheat straw prepared by farm women as complete feed on milk yield of lactating buffaloes of Mehsana district, Gujarat
}

\section{S.M. SONI AND M.V. PATEL}

Article Chronicle : Received :

11.06.2015;

Revised :

24.07.2015;

Accepted :

23.08.2015

KEY Words:

Buffalo, Milk

production, Urea

treated wheat straw
SUMMARY : Front line demonstration was conducted on 180 lactating buffaloes, were randomly divided into two groups on the basis of milk yield ( 7 to $8 \mathrm{~kg} /$ day) and day of calving less than 60 days to see the effect of feeding urea treated wheat straw on milk production for continuous three years (2012-2013, 2013-2014,2014-2015). Buffaloes were fed concentrate, green and dry fodder and un treated wheat straw in control groups and concentrate, green and dry fodder and urea treated wheat straw was given in treatment group. Experimental feeding was continued upto 90 days. The average milk production was significantly higher in treatment group. It was concluded that animals fed with urea treated wheat straw significantly increase the milk production over the control group.

How to cite this article : Soni, S.M. and Patel, M.V. (2015). Front line demonstration on effect of urea treatment of wheat straw prepared by farm women as complete feed on milk yield of lactating buffaloes of Mehsana district, Gujarat. Agric. Update, 10(3): 259-261.

Author for correspondence :

\section{M.V. PATEL}

Krishi Vigyan Kendra,

Ganpat Vidyanagar,

MEHSANA (GUJARAT)

INDIA

Email: kvkmehsana@

yahoo.co.in

See end of the article for

authors' affiliations 